\title{
Type-Specific HPV Antibody
}

National Cancer Institute

\section{Source}

National Cancer Institute. Type-Specific HPV Antibody. NCI Thesaurus. Code C154138.

Any immunog lobulin that recognizes the human papillomavirus serotype(s) in a vaccine following inoculation. 